\title{
Conditions of fluid-rock interactions and related chemical mobilities in magma-poor rifted margins: insights from rodingites and serpentinites.
}

\author{
MARC UlRICH ${ }^{1}$, MÉDERIC AMANN ${ }^{1}$, MANUEL MUÑOZ ${ }^{2}$, \\ DAMIEN LEMARCHAND ${ }^{3}$, ERIC PELT ${ }^{3}$, DANIEL SAUTER ${ }^{1}$ \\ AND GIANRETO MANATSCHAL ${ }^{1}$. \\ 'IPGS-EOST, CNRS UMR 7516, University of Strasbourg, 1 \\ Rue Blessig 67084 Strasbourg, France \\ ${ }^{2}$ Geosciences Montpellier, CNRS UMR 5243, University of \\ Montpellier, Place E. Bataillon, 34095 Montpellier, \\ France \\ ${ }^{3}$ LHyGeS-EOST, CNRS UMR 7516, University of Strasbourg, \\ 1 Rue Blessig 67084 Strasbourg, France
}

Recent studies have demonstrated that tectonic, magmatism and hydration are key features that control oceanization processes from the rifting to the establishment of the first oceanic crust. Therefore, studying Ocean-Continent Transitions (OCTs) provides a unique opportunity to investigate interactions between mantle rocks, melts and fluids and assess their feedback mechanisms and enhancers. The Upper Penninic Platta nappe (SE Swiss Alps) is one of the best preserved fossil OCT documented so far: it consists of exhumed subcontinental, highly serpentinized peridotites crosscut by numerous rodingitized magmatic dikes. Based on comprehensive mineralogical and geochemical investigations of contacts between serpentinites and rodingites, this study aims at determining the conditions of fluid-rock interactions (temperature, $\mathrm{pH}$ ) and the associated chemical mobility during their exhumation at seafloor.

Mineralogical investigations show that rodingites consist of an assemblage of chlorite, hydrogrossular and several generations of clinopyroxene, while serpentinites display a typical mesh texture of lizardite where relics of primary minerals (olivine + pyroxenes) are rare. At the contact with dikes, serpentinites are converted into a chlorite reaction zone (blackwall) where clinochlore has almost completely replaced serpentine. Trace element patterns of blackwalls are similar to those of rodingites, suggesting that elements, even those considered as highly immobile (i.e. $\mathrm{Al}, \mathrm{Zr}$ ), may be transferred from the dikes to the surrounding mantle during the rodingitization. Finally, based $\mathrm{Sr}$ and B isotopes, we show that fluid-melt interactions occurred at a wide range of temperature, from $\sim 200$ to $60^{\circ} \mathrm{C}$. This suggests that the rodingitization process recorded fluid-rock interactions at depth, and that this process may remain active at very shallow depths. 